\title{
Customer Orientation of Service Employees: A Phantom Model Approach
}

\author{
Reema Farooghi \\ Khadim Ali Shah Bukhari Institute of Technology or KASB \\ Institute of Technology \\ Syeda Nazneen Waseem \\ Iqra University \\ Samina Qasim, \\ Iqra University
}

\begin{abstract}
Purpose: The purpose of this study is to analyze Customer Retention as a result of Customer Service Employees. It helps to study the attitude of the customers and analyze the factors that are held important by the customers towards achievement of their satisfaction. Methodology: CFA and Path Analysis have been used to analyze the data collected from young telecom users. Data has been collected using convenience sampling from young telecom consumers using self-administered questionnaire.

Findings: The results indicate that there is a significant relationship between Customer Orientation of Service Employees and Customer Retention, Customer Satisfaction and Emotional Commitment. It is also analyzed that there Customer Satisfaction and Emotional Commitment mediates the effect between Customer Orientation of Service Employees (COSE) and Customer Retention.

Practical Implications: This study contributes in a number of ways. First it provides an understanding regarding the relationship of Service Employees and Customer Retention. Secondly it helps to analyze the criteria that need to be used so as to increase customer satisfaction and their involvement in the organization; thirdly it provides empirical evidence of the work and theory laid by Hennig-Thurau, 2004.
\end{abstract}

Keywords: Customer Orientation of Service Employees, COSE, Customer Satisfaction, Customer Retention, Emotional Commitment, Telecommunication Industry.

\footnotetext{
* The material presented by the author does not necessarily portray the viewpoint of the editors and the management of the Institute of Business \& Technology (IBT)

1 Reema Farooghi

:reemafrooghi@yahoo.com

(C) IBT-JBS is published by the Institute of Business and Technology (IBT).

Main Ibrahim Hydri Road, Korangi Creek, Karachi-75190, Pakistan.
} 


\section{CONCEPTUALIZING CUSTOMER ORIENTATION OF SERVICE EMPLOYEES - COSE}

The evolution of marketing concept within service industry is a result of employee interaction with their customers (Gazzoli and Hancer, 2013). Customer orientation being an individual level construct plays a vital role in in determination of organization ability to be market-oriented (Brown et al., 2002; Gazzoli and Hancer; 2013).Service employees with more focus on customer orientation spend more time on satisfaction of customer needs which helps in developing more beneficial long term relationship with the customers (Kelley, 1992; Kotler, 1980). Customer Orientation at individual level is defined by two aspects; behavioral level and self-personality trait level (Saxe and Weitz, 1982; Hennig-Thurau and Thurau, 2003).

Saxe and Weitz (1982) have studied Customer Orientation based on behavioral level; selling orientated and customer oriented SOCO Scale. Hennig-Thurau and Thurau (2003) have studied COSE as a three dimensional construct customer-oriented skills; motivation to serve customers; self-perceived decision making authority. Based on the prior work done Hennig-Thurau (2004) has developed a new COSE construct which is based on four dimensions; technical skills, social skills, motivation, self-perceived decision making authority, as shown in Figure - 1. COSE has been elaborated as degree to which the employee's behavior in individual connections with customers meets those customers' needs (Henning-Thurau, 2004). All four dimensions of COSE are interlinked with each other to an extent which enables the employees to perform in a way which helps towards customer satisfaction. Technical skills are described as the knowledge and expertise withheld with the service employees to understand and solve the problems of the customers during the interaction being carried out (Argyle, 1967). These skills are important for need fulfillment of the customer during the interaction being taken place.

Social skills are employee's ability to understand and analyze the customer perspective during interaction process (Flavell et al., 1968; Mead, 1934). It is important to study customer requirements and shape the offerings in a way which helps fulfill their needs and creates satisfaction within them. As described by Flavell et al. (1968) there exist three elements with such perspective that includes:

1. Visually - the employees understanding of what customer sees and perceives.

2. Cognitively - understanding what customer thinks.

3. Emotionally - understanding what customer feels.

These three aspects empower the employee to comprehend the customer's requirements and are in this way thought to be essential for need satisfaction. Social skills are demonstrated independently here from Technical skills to reflect sufficiently the distinctive hypothetical starting points and streams of research these two ideas are in light of. It is not necessarily important that the employee who is having high level of social skill also has high level of technical skills to exhibit such behavior that is important to perform in customer-oriented manner (Hennig-Thurau, 2004). 
Employee's motivation towards serving customers consists of three elements, which are: a positive relationship between customer-oriented behavior and associated relationship between the behaviors as part of employees, self-perception of the employees to have skills so as to perform according to customer needs (Vroom, 1967), and employees expectation of reaching on employees desired outcome through engagement in such behavior(Hennig-Thurau, 2004). Motivation is an incumbent tool for transforming social and technical skills of employees into customer-oriented activities (HennigThurau, 2004).

Self-decision making authority as discussed in different researches is related to empowering employees to take decisions based on analysis of customer needs and creation of customer satisfaction (Bowen and Lawler, 1995; Spreitzer, 1995). It emphasizes on the level of authority given to the employees to take decisions on customer related concerns and matters (See Figure-1 in appendix).

\section{LITERATURE REVIEW}

Services being intangible, inseparable and interactive in nature (Hennig-Thurau, 2004) is consumed and evaluated by the consumers in the presence of service employees (Teng and Barrows, 2009). Therefore service quality not only plays an important role in the decision making process by the customer but the interaction between service employees and customers also effect the evaluation process (Gazzoli and Hancer, 2013).Service orientation as defined by Goleman (1998) is defined as anticipation and fulfillment of customer's needs. Service orientation has been studied at two levels:

1. Service orientation as a personality Trait (Hogan et al., 1984; McBride et al., 1997).

2. What employees do and how they perform in service industry (Jayawardhena and Farrell, 2011).

\subsection{Customer Orientation of Service Employees - COSE}

Customer Orientation refers to understanding and fulfillment of customer needs during a transaction taken place, whereas service orientation goes beyond the framework of it as it also incorporates after sales service and assistance provided to the customers after the transaction taken place (Popli and Rizvi, 2015). Literature defines the salesorientated service person focusing on making numbers while a customer orientated sales person focuses on maximization of customer satisfaction. The attitude developed by a customer orientated sales person helps in understanding customer's perspective which in turn helps to increase profit of the company. He not only works sincerely with 
the customer but also assists in need fulfillment (Colwell et al., 2009). A customer creates a strong belief that the service employees foster hard work to develop their interest, therefore it becomes important to develop attitude and behavior which helps in attracting customer towards the business. Understanding customer need helps in development of customized offering for the customer and can easily recommend products and services.Organizational psychologists state that those employees who are having strong bonds with the organization are more likely to develop deeper bond with the customers due to familiarity with the organizational working procedures (Sluss and Ashforth, 2008). Researchers also assert on the learning that rendering high level of responsibility by the employees towards the customer is a key towards organizational success (Ahearne et al., 2005).Customer identification is not only an important element towards increasing job engagement among frontline employees but it also helps in development of employee organizational identification and employee satisfaction (Anaza and Rutherford, 2012).

Brady and Conin (2001) identifies that employee's attitude, their behavior and expertise are the key attributes to define perception of the customer regarding the service quality. Customer satisfaction and customer retention is achieved through employee's quality relationship developed by the customer (Gazzoli and Hancer, 2013). For example a service employee who:

1. Anticipates and understands the needs of the customer.

2. Nurtures the customer.

3. Delivers service on time.

4. Tries to know the customer personally through utilization of their social skills.

The support and encouragement received by the employees by their supervisor and higher management helps in deliverance of high quality service (Karatepe et al., 2008). Training provided to the employees facilitates to enhance the technical skills of the employees for resolution of customer complaints and queries (Tsaur and Lin, 2001; Karatepe et al., 2008).

Training projects supported by an organization can enhance representatives' undertaking related and behavioral aptitudes; improve their capacity to manage shifting client needs, identities and circumstances viably (Babakus, 2010). Employees who get preparing get to be more skilled and roused, and give larger amounts of administration. In contrast, employees who don't have the imperative occupation and interpersonal aptitudes neglect to give palatable administration and can't manage client requests and grievances viably (Boshoff and Allen, 2000).

Empowerment provides with the service employees authority and responsibility to take decisions without following a long chain of command (Babakus et al., 2003; Karatepe at al., 2008). Providing decision making authority to the employees helps the employees to become flexible and get closer to the customers as it enables employees 
for provision of timely responses.

\subsection{Employee Motivation and their Engagement}

Motivated Employeesare highly engaged in the activities they perform at work, this is due to Organizational Commitment and Organizational Citizenship Behavior (Popli and Rizvi, 2015). Motivationdeals with employee commitment towards workplace; it shows how much an employee is aware regarding organizational culture and what is the behavior that needs to be exhibited during the responsibilities being carried out at workplace (Popli and Rizvi, 2015).For employees to show job commitment three elements are compulsory; availability, safety at workplace and meaningfulness of job being performed (Kahn, 1990; Popli and Rizvi, 2015). During work task completion engagement refers to active use of emotions and cognitive behavior (May et al., 2004; Popli and Rizvi, 2015). Three levels of engagement have been described by Meere (2005):

1. Employees who work with passion, those who feel themselves an integral part of the organization and thinks innovatively for the organization.

2. Those who attend work and fulfill their responsibilities only during their working hour but don't feel themselves as part of the organization.

3. Those who are unhappy at work and show unhappiness in performing duties and tasks.

Employees receiving more support from their coworkers obtain more job resources which facilitates them to deal effectively with stressful and difficult customers (Bakker et al., 2005; Tsai et al., 2007). This support not only help employees to meet and solve customer related problems and concerns but also to be persistent in their daily work activities (Liaw et al., 2010). A highly engaged employee not only contributes positively towards the organization but organizational success is also dependent on them (Saks, 2006). There exists a positive relationship between employee engagement and organizational success. Highly motivated and engaged employees facilitate the industrial growth process and helps in increasing organizational growth (Markos and Sridevi, 2010).

\subsection{Social Skills and Customer Interaction}

Sales person's characteristics has been analyzed on two different dimensions; one which involves alteration of sales behavior during customer interaction and other and second marketing services based on the conceptual level of the one perceiving it. These two approaches help in developing long-term customer relationship as it creates a tool to tailor messages according to an individual's needs and perception (Franke and 
Park, 2006).

Service outcomes are improved by the friendly attitude and behavior of the customer service personnel (Sabiote and Roman, 2009).Friendly behavior includes; familiarity, frankness, trustworthiness, politeness, caring and understanding customer needs. A customer feels insulted if not treated with love and respect; a customer evaluates its satisfaction level on the basis of respect he/she receives. A courteous service provider is researched out to be a powerful signal of service quality (Sabiote and Roman, 2009).Previous researches indicate that as the length of the relationship with the customer service increases aspects of interaction becomes less important for the customer.

The key aspect that develops social construct comprises of: 1) taking interest in customer's interest, 2) developing a feeling within the customer that he/she is important, 3) giving respect to customer, 4) being courteous and polite with the customer and 5) exhibiting a genuine and truthful behavior (Sabiote and Roman, 2009).

\subsection{Customer Commitment}

Customer commitment and repurchase behavior are highly important for the service organization as their growth and profitability is dependent on it (Palmatier el al., 2006). Customer's decision to purchase, re-purchase is dependent on the quality of service, satisfaction from the service and trust that has been developed on the supplier (Carrillat et al., 2009). Nevertheless, economic and non-economic factors are also at times considered as factors that affect the decision making criteria of the customer (Valenzuela et al., 2010). Suppliers who exhibit ethical behavior have favorable reputation in the market and their service offerings are also seen and analyzed favorably, customers are more likely to be associated with such service providers for a greater period of time (Ahearne at al., 2005). Studies have revealed that ethical behavior and reputation of the service providers helps in creation of trust among the customers which in turn leads to satisfaction and customer commitment (Henning-Thurau, 2004; Huang, 2008).

Customer oriented firms put effort on taking care of customer needs. They constantly monitor the change in customer requirements and also the changing market trend and practices (Valenzuela et al., 2010), so that they can adapt themselves towards the changing patterns and trends (Min et al., 2007).The attitude adopted by the service provider's result in better relationship quality and positive word of mouth (Macintosh, 2007), there exist a strong relationship between customer orientation and customer commitment (Homburg et al., 2009; Huang, 2008).

\subsection{Customer Satisfaction}

Customer satisfaction has been subject of attention because of consumer behavioral intention and customer retention (Dholakia and Zhao, 2010; Cronin et al., 
2000). Cultivation of relationship with the customers has thought to increase customer satisfaction (Kim, 2009). Long-term connections add additional qualities to customers' administration utilization and consequently add to client fulfillment (Kim, 2009). There exists a positive relationship between customer perceived value and customer satisfaction (Jayawardhena and Farrell, 2011). Three antecedents of customer satisfaction have been discussed: perceived value, perceived quality and customer expectation (Jayawardhena and Farrell, 2011). Perceived value is considered either pre or post purchase (Eggert and Ulaga, 2002). The customer not only compares the cost of the service with the benefits he/she receives but also may not want to avail the service if the perceived quality is low (Eggert and Ulaga, 2002).

Word of mouth which is defined as an informal communication among consumers regarding ownership, characteristics and usage of products and services is an important marketing tool for the service industry, as it involves high level of risk and difficulty in evaluation process (Sabiote and Roman, 2009).

\subsection{Customer Retention}

Customer retention is termed as customer's continuation with the firm (Keningham, 2007). Customer retention is an elementary element towards firm's profitability (Keningham, 2007). It has been an important element of study since 1990's (Ang andButtle, 2006), as marketing department of firms feel that it is more important to retain prior customer than attracting new ones (CoylesandGokey, 2005), as more cost and energy is required in attracting new customers than retaining old ones (AydinandOzer, 2005; Keningham, 2007).Customer retention has been a burning concern today as it facilitates organizations to reach its objectives and goals, through creation of delightedness a customer retains with the organization service for a greater period of time (Gee et al., 2008). Organizations who are aware regarding the importance of customer retention invest towards them even from their profits as they in return give long term benefits and profits to the organization (Ang and Buttle, 2006). There are many aspects that influence customer retention but development of trust is more important for an organization to be built (Sarwar et al., 2012).

\section{CRITICAL OVERVIEW OF LITERATURE}

In today's competitive market there can be few organizations who don't strive to be client centered, and even less who don't perceive how critical workers are in conveying this. Strong associations are created by providing best quality service and fulfilling the promises made to the client. An organization that provides greater level of customer service demonstrates three functions; understanding customer's expectation, monitoring of competitor service performance level and ensuring delivery of superior quality service to their valued customers. According to the social exchange theory it is argued that increase in customer's perceived value, through provision of benefits 
nurtures customer loyalty and retention. It is hoped that the loyal customer benefits the organization by spreading a positive word of mouth and being a source for attracting prospect clients.

Service organizations should begin to think the role their employees play towards customer satisfaction which facilitates towards customer retention. This helps in achievement of competitive advantage for the service providing organization. Receiving recognition and support from the organization and upper management not only leads towards job satisfaction but also helps in creation of customer oriented culture, as delighted employees result in delighted customers. Loyal customers are regarded as cornerstone for any organization and employees are the ones who help in retention of those customers. Organizational growth and profitability is dependent on the life-time a customer spends with the organization and the word of mouth they spread regarding the experience they have enjoyed with the service provider. An organizational culture that fosters favorable service climate leads to behaviors and attitudes within employees that creates higher value and provide better and favorable results.

Within Pakistani industry little attention has been paid on how within an organization customer orientation can be disseminated. For any organization the integral element that results in productivity is how much profitable that organization is and the life span it has in the given industry. An engaged employee puts all the efforts towards organizational success and productivity. An engaged employee though not part of his specific job responsibility goes beyond his borders to resolve customers concerns and queries, or arranges for another subordinate who can help the customer in resolution of their queries and concerns. They not only do a better job towards servicing people but go beyond their responsibilities and perform an active role towards fulfillment of customer needs.

Therefore within Pakistani context, it is important to analyze the factors that facilitates in empowering the employees so that the exhibit behaviors and attitudes favorable towards organizational success and growth. This research will help to study and analyze the factors that impact towards customer retention as it is becoming an important concern for marketers today. The focus of this research is inclined towards the perception of the customers regarding the attitudes and behavior of the service providing employees. What do they think and feel regarding the delivery and quality of service they receive and how do they evaluate these employees. It will put light on the strategies which an organization should develop and focus on for grooming customer oriented employees so as to achieve organizational success.

\section{HYPOTHESIZED MODEL}

Figure .2 indicates the hypothesized model along with the paths under study in the given paper. It provides and analysis and study pattern of the variables under study (See Figure-2 in appendix): 
H1: COSE has a significant impact on Customer Satisfaction.

H1a: Customer Satisfaction mediates the relationship between COSE and Customer Retention.

H2: COSE has a significant impact on Emotional Commitment.

H2a: Emotional Commitment mediates the relationship between COSE and Customer Retention.

H3: COSE has a significant impact on Customer Retention.

H4: Customer Satisfaction has a significant impact on Customer Retention. H5: Emotional Commitment has a significant impact on Customer Retention. H6: Customer Satisfaction has a significant impact on emotional commitment.

\section{RESEARCH METHDOLOGY}

\subsection{Sampling and Data Collection Methodology}

A sample of 258 respondents was collected for the study. Convenience sampling has been adopted for data collection and the respondents comprise of young customers of Mobile Service providers. Data has been collected both through offline and online medium using self-administered questionnaire, presented in Table - 4.

\subsection{Measures}

The questionnaire comprised of 7 variables, namely: Social Skills, Motivation, Technical Skills, Decision Making Authority, Customer Retention, Customer Satisfaction and Emotional Commitment.

\subsection{Customer Orientation of Service Employees - COSE}

COSE termed as Customer Orientation of Service Employees comprises of fourdimensions: Social Skills, Technical Skills, Decision Making Authority and Motivation. The items have been extracted from Hennig-Thurau, 2004. Sample items include: "The employees of the mobile network have a high level of knowledge" (Technical Skills), "The employees of the mobile network have extensive social skills" (Social Skills), "The employees of the mobile network show strong commitment to their job" (Motivation) and "The employees of the mobile network are allowed to decide autonomously in customer matters" (Decision Making Authority). The items have been measured on a Likert Scale of 1 - 5 from Strongly Disagree to Strongly Agree.

\subsection{Customer Satisfaction}


The items of Customer Satisfaction have been adopted from HennigThurau, 2004. Sample items include "I am fully satisfied with the mobile network". The items have been measured through a five point Likert Scale from $1=$ Strongly Disagree to $5=$ Strongly Agree.

\subsection{Emotional Commitment}

The items of Emotional Commitment have been adopted from HennigThurau, 2004. Sample items include "If the network is use were no longer to exist, this would be a significant loss for me". The items have been measured through a five point Likert Scale from $1=$ Strongly Disagree to $5=$ Strongly Agree.

\subsection{Customer Retention}

The items of Customer Retention have been adopted from Hennig-Thurau, 2004. Sample items include "The mobile network I use is my first choice when it comes to buying a new SIM". The items have been measured through a five point Likert Scale from $1=$ Strongly Disagree to $5=$ Strongly Agree.

\section{DESCRIPTIVE STATISTICS AND TESTING THE ASSUMPTIONS OF MULTIVARIATE ANALYSIS}

Data analysis has been carried out through SPSS 21 and AMOS 21 software. Sample size of the study conducted is $\mathrm{N}=258$. Multivariate outliers were removed using Mahalanobis Technique. After removing the multivariate outliers the sample size of the study is $\mathrm{N}=245$.Table -1 elaborates the demographics and the composition of the data used in the study. Before carrying out the data analysis assumptions of SEM were checked; sample size, normality within the variables, outliers, scales of the variables and multicollinearity (Hair et al., 2005; Fotopulos and Psomas 2009), the Cronbach value of the instrument used is calculated to be 0.905 which meets the desired requirements. According to Hair et al., (2005) for a study the adequate sample size is 50 to 400 observations; in the given study the sample size is $\mathrm{N}=245$ which is adequate as per the requirement. For analysis of normality the acceptable range of Skewness and Kurtosis is \pm 1 , which indicates a symmetric distribution (Fotopulos and Psomas 2009). Table -1 indicates that the data is normal as the values lie between desired ranges. Univariate outliers were removed from the data set using mean method; so as to fulfill the assumptions of SEM (See Table-1 in appendix).

\section{CONFIRMATORY FACTOR ANALYSIS $-2^{\text {nd }}$ ORDER}

The measurement model is tested using AMOS 21. The measurement model comprises of 24 items that helps to explain 7 factors namely; Social Skills, Technical Skills, Decision Making Authority, Motivation, Customer Satisfaction, Emotional Commitment and Customer Retention. The measurement model has been tested to evaluate the construct validity and the reliability of the given scales. Composite Reliability has been used as an indicator for construct validity as it helps in measuring the reliability of the overall scale being used. (Fornell\&Larcker, 1981; Lin \& Lee, 2004; 
Molina, Llor_ens-Montes, \& Ruiz-Moreno, 2007).Table - 1 indicates Average Variable Explained for each of the variable used in the model and it indicates that the model is a good fit model. The issue of multicollinearity was also studied and it was analyzed that no issue of multicollinearity exists as all the Pearson $r$ values are below threshold point of 0.90 (Anderson, 2010), as shown in Table - 2 (See Table-2 in APPENDIX).

CFA model which depicts a link between the observed and the unobserved variable (Byrne, 2013) is shown in Figure - 3. For measurement of goodness of fit of the measurement model, four common measures has been used; CMIN/DF as proposed by Byrne (2013), TLI as proposed by Bentler (1990), CFI as proposed by Bagozzi and Yi (1988) and RMSEA as proposed by Browne and Cudeck (1993).

As shown in Table -3 the CMIN/DF value of our CFA model ( $1^{\text {st }}$ order) is calculated as 1.788 , TLI value is 0.907 , CFI value is calculated as 0.926 and RMSEA value is measured to be 0.057 which is satisfied cut-off level values described by different authors (See Figure-3 in APPENDIX).

$2^{\text {nd }}$ Order CFA model, Figure - 4, was developed so as to develop a new latent variable COSE - Customer Orientation of Service Employees, which describes the variables named Social Skills, Technical Skills, Decision Making Authority and Motivation. The model was measured for its goodness of fit, Table - 3, CMIN/DF value is calculated as 1.801, TLI value is 0.906 , CFI value is 0.921 and RMSEA value is calculated to be 0.057 (See Table-4 in APPENDIX).

(See Figure-5 in APPENDIX)

\section{PATH ANALYSIS AND HYPOTHESIS TESTING}

Path analysis was carried out to test the significance of hypothesized regression paths, Figure -5 . Byrne (2013) emphasizes that for making the hypothesized part supported the value to C.R should be $>$ that \pm 1.96 . Table -5 indicates the path coefficient, critical ratio, standard error and significance value of each path; which helps to support the hypothesis (See Table-5 in APPENDIX).

The result indicates that Customer Orientation of Service Employees (COSE) has a positive and significant impact on Website Satisfaction ( $\hat{a}=0.931, p<0.05$ ), Emotional Commitment ( $\hat{\mathrm{a}}=0.330, \mathrm{p}<0.05)$; and negative but significant impact on Customer Retention ( $\hat{\mathrm{a}}=-0.306, \mathrm{p}<0.05)$. Hence hypothesis $\mathrm{H} 1, \mathrm{H} 2$ and $\mathrm{H} 3$ are supported.

On the other hand the result indicates that Customer Satisfaction has a positive and significant impact on Customer Retention ( $\hat{a}=0.162, p<0.05)$, Emotional Commitment has positive and significant impact on Customer Retention $(\hat{a}=1.430$, 
Commitment ( $\hat{a}=0.367, p<0.05$ ) (See Figure-6 in APPENDIX).

10. MULTIPLE MEDIATION ANALYSIS USING PHANTOM MODEL

For analysis of mediating effect Customer Satisfaction and Emotional Commitment in relation of Customer Orientation of Service Employees (COSE) and Customer Retention, Phantom model has been adopted, Figure - 5. The Phantom Approach is a convenient and powerful method for arbitrary specific effect comparison, testing and estimation of variables within the SEM structure. Table -6 represents the accumulated result of the Phantom Approach, showing a full mediator influence of Customer Satisfaction and Emotional Commitment on COSE and Customer Satisfaction (See Table-6 in APPENDIX).

Analysis of relationship of Customer Satisfaction and Emotional Commitment on effect of COSE on Customer Retention shows that Customer Satisfaction has nonsignificant mediating effect on COSE and Customer Retention (0.931, p > 0.053), whereas Emotional Commitment has a significant mediating relationship on COSE and Customer Retention $(0.960, p<0.05)$, Table -7 . The result indicates that the entire mediating effect is due to the presence of Emotional Commitment in the model (See table-7 in APPENDIX).

\section{DISCUSSION AND CONCLUSION}

The present study has been conducted to analyze the relationship between the Service Employees attitudes, behavior and the authority that is floated towards them on customer satisfaction, their emotional commitment and customer retention. The study carried out within the Telecom sector of Pakistan shows that there exists a strong relationship between service employee's and customer satisfaction, their retention and their emotional commitment.

Customer Orientation of Service Employees has a positive and significant relationship towards customer satisfaction $(\hat{\mathrm{a}}=0.931, \mathrm{p}<0.05)$, and also with Emotional Commitment ( $\hat{\mathrm{a}}=0.330, \mathrm{p}<0.05)$; which supports the study carried out by Sluss and Ashforth, 2008 \&Anaza and Rutherford, 2012. With increase in Customer Satisfaction and Customer's Emotional Commitment,Customer Retention increases positively and with a greater extent, as supported by the study carried out by Ahearne et al., 2005. The findings of this research support the theory developed by Hennig-Thurau, 2004. There exist a positive relationship between the attitude and the authority of the service employees towards satisfaction. With the increase in authority and decision making skills present in these employees the satisfaction ratio of the customer increases which in result helps in increasing the retention ratio of the customers. The growth of service industry is dependent on how the employees interact with the customers, which isinline with the study carried out by (Gazzoli and Hancer, 2013).

\section{MANAGERIAL IMPLICATIONS}


This research paper will help Telecom Industry to analyze the factors that support towards customer retention. The Authority that is possessed by the Customer Service employees help them to take quick and prompt decisions which in results helps towards increasing Customer Retention ratio. Telecom Service industry needs to focus more on Service Employees skills and abilities as they are the people who are in direct contact with the end users and they not only help in retaining customers by analysis and timely fulfillment of their needs, but also are a source to attract prospects customers.

As Service Employees are a source of attraction for the customers therefore companies should focus on their training and development and also evaluate their performance so that they can improve their skills and abilities. Benefits also need to be provided to the employees who work wholeheartedly towards achievement of organizational goals and purpose.

Companies need to understand that Customer Retention is a result of Customer Satisfaction and Emotional Commitment of the customers. Therefore strategies need to be developed for increasing customer commitment towards the organization so as to increase organizational profitability.

\section{RESEARCH LIMITATIONS\& FURTHER AREAS OF RESEARCH}

Although the research conducted provides an in-depth analysis of customer's attitude and response towards service employees, hence there still exist certain limitations and further areas of study of the research. This research has been carried out on telecommunication sector; it can be spread and conducted on other industries.

Young consumers have been studied in this research; the sampling frame can be shifted from young consumers towards other consumer group also. Furthermore, analysis can be done on Service employees end so as to analyze the gap that creates a discrepancy between their actual and desired performance.

\section{REFERENCE}

Byrne, B. M. (2013). Structural equation modeling with AMOS: Basic concepts, applications, and programming. Routledge.

Bentler, P. M. (1990). Comparative fit indexes in structural models. Psychological bulletin, 107(2), 238. 
Ahearne, M., Bhattacharya, C. B., \&Gruen, T. (2005). Antecedents and consequencesof customer-company identification: expanding the role of relationship marketing. ÊJournal of applied psychology, $\hat{E} 90(3), 574$.

Anaza, N. A., \& Rutherford, B. (2012). How organizational and employee-customer identification, and customer orientation affect job engagement. Journal of Service Management, $\hat{E} 23(5), 616-639$.

Anderson, R. E., \& Srinivasan, S. S. (2003). E-satisfaction and e-loyalty: A contingency framework.ÊPsychology \& marketing,ÊE20(2), 123-138.

Ang, L., \&Buttle, F. (2006). Customer retention management processes: A quantitative study. European journal of marketing, 40(1/2), 83-99.

Argyle, M. (1994). The psychology of interpersonal behavior. Penguin UK.

Aydin, S., Özer, G., \&Arasil, Ö. (2005). Customer loyalty and the effect of switching costs as a moderator variable: A case in the Turkish mobile phone market. Marketing Intelligence \& Planning, 23(1), 89-103.

Babakus, E., Yavas, U., Karatepe, O. M., \&Avci, T. (2003). The effect of management commitment to service quality on employees' affective and performance outcomes. Journal of the Academy of Marketing Science, 31(3), 272-286.

Bagozzi, R. P., \& Yi, Y. (1988). On the evaluation of structural equation models. Journal of the academy of marketing science, 16 (1), 74-94.

Bakker, A. B., Demerouti, E., \&Schaufeli, W. B. (2005). The crossover of burnout and work engagement among working couples. Human Relations, 58(5), 661-689.

Berry, L. L., Seiders, K., \&Grewal, D. (2002). Understanding service convenience. Journal of marketing, 66(3), 1-17. 
Boshoff, C., \& Allen, J. (2000). The influence of selected antecedents on frontline staff's perceptions of service recovery performance. International Journal of Service Industry Management, 11(1), 63-90.

Bowen, D. E., \& Lawler, E. E. (1995).ÊEmpowering service employees. Cambridge, MA: MIT press.

Brady, M. K., \& Cronin, J. J. (2001). Customer orientation effects on customer service perceptions and outcome behaviors. Journal of service Research, 3(3), 241-251.

Brockman, B. K., Jones, M. A., \&Becherer, R. C. (2012). Customer Orientation and Performance in Small Firms: Examining the Moderating Influence of Risk-Taking, Innovativeness, and Opportunity Focus. Journal of Small Business Management, 50(3), 429-446.

Brown, T. J., Mowen, J. C., Donavan, D. T., \& Licata, J. W. (2002). The customer orientation of service workers: Personality trait effects on self-and supervisor performance ratings. Journal of Marketing Research, 39(1), 110-119.

Browne, M. W., \&Cudeck, R. (1993). Alternative ways of assessing model _t. Sage Focus Editions.

Carrillat, F. A., Jaramillo, F., \&Mulki, J. P. (2009). Examining the impact of service quality: a meta-analysis of empirical evidence. The Journal of Marketing Theory and Practice, 17(2), 95-110.

Colwell, S., Hogarth-Scott, S., Jiang, D., \& Joshi, A. (2009). Effects of organizational and service person orientation on customer loyalty. Management Decision, 47(10), 1489-1513.

Coyles, S., \&Gokey, T. C. (2002). Customer retention is not enough. The McKinsey Quarterly, 2(2), 81-89.

Cronin, J. J., Brady, M. K., \&Hult, G. T. M. (2000). Assessing the effects of quality, value, and customer satisfaction on consumer behavioral intentions in service environments. Journal of retailing, 76(2), 193-218. 
Devaraj, S., Matta, K. F., \& Conlon, E. (2001). Product and service quality: the antecedents of customer loyalty in the automotive industry. Production and Operations Management, 10(4), 424-439.

Donavan, D. T., Brown, T. J., \&Mowen, J. C. (2004). Internal benefits of service-worker customer orientation: Job satisfaction, commitment, and organizational citizenship behaviors. Journal of marketing, 68(1), 128-146.

Eggert, A., \&Ulaga, W. (2002). Customer perceived value: a substitute for satisfaction in business markets?.Journal of Business \& industrial marketing, 17(2/3), 107118.

Flavell, J. H. (1968). The development of role-taking and communication skills in children.

Fornell, C., \&Larcker, D. F. (1981). Evaluating structural equation models with unobservable variables and measurement error. Journal of marketing research.

Fotopoulos, C.B. and Psomas, E.L. (2009), "The impact of soft and hard TQM elements on quality management results", International Journal of Quality \& Reliability Management, Vol. 26 No. 2, pp. 150-63.

Franke, G. R., \& Park, J. E. (2006). Salesperson adaptive selling behavior and customer orientation: a meta-analysis. Journal of Marketing Research, 43(4), 693-702.

Gazzoli, G., Hancer, M., \& Kim, B. (2013). Explaining why employee-customer orientation influences customers' perceptions of the service encounter. Journal of Service Management, 24(4), 382-400.

Gee, R., Coates, G., \& Nicholson, M. (2008). Understanding and profitably managing customer loyalty. Marketing Intelligence \& Planning, 26(4), 359-374.

Goleman, D. (1998). Working with emotional intelligence. Bantam.

Hair, J.F., Black, W.C., Babin, B.J., Anderson, R.E. and Tatham, R.L. (2005), Multivariate 
Data Analysis, 6th ed., Pearson Prentice Hall, Englewood Cliffs, NJ.

Hennig-Thurau, T. (2004). Customer orientation of service employees: Its impact on customer satisfaction, commitment, and retention. International Journal of Service Industry Management, 15(5), 460-478.

Hennig-Thurau, T., \&Thurau, C. (2003). Customer orientation of service employeesToward a conceptual framework of a key relationship marketing construct. Journal of Relationship Marketing, 2(1-2), 23-41.

Hogan, J., Hogan, R., \& Busch, C. M. (1984). How to measure service orientation. Journal of Applied Psychology, 69(1), 167.

Homburg, C., Wieseke, J., \& Hoyer, W. D. (2009). Social identity and the service-profit chain. Journal of Marketing, 73(2), 38-54.

Huang, M. H. (2008). The influence of selling behaviors on customer relationships in financial services. International Journal of Service Industry Management, 19(4), 458-473.

Jayawardhena, C., \& Farrell, A. M. (2011). Effects of retail employees' behaviours on customers' service evaluation. International Journal of Retail \& Distribution Management, 39(3), 203-217.

Kahn, W. A. (1990). Psychological conditions of personal engagement and disengagement at work. Academy of management journal, 33(4), 692-724.

Karatepe, O. M., Yavas, U., \&Babakus, E. (2007). The effects of customer orientation and job resources on frontline employees' job outcomes. Services Marketing Quarterly, 29(1), 61-79.

Keiningham, T. L., Cooil, B., Aksoy, L., Andreassen, T. W., \& Weiner, J. (2007). The value of different customer satisfaction and loyalty metrics in predicting customer retention, recommendation, and share-of-wallet. Managing Service Quality: An International Journal, 17(4), 361-384. 
Kelley, S. W. (1992). Developing customer orientation among service employees. Journal of the Academy of Marketing Science, 20(1), 27-36.

Kim, W. (2009). Customers' Responses to Customer Orientation of Service Employees in Full-Service Restaurants: A Relational Benefits Perspective. Journal of Quality Assurance in Hospitality \& Tourism, 10(3), 153-174.

Kompaso, S. M., \&Sridevi, M. S. (2010). Employee engagement: The key to improving performance. International Journal of Business and Management, 5(12), p89.

Kotler, P. (1980). Marketing management: analysis, planning and control. PrenticeHall.

Liaw, Y. J., Chi, N. W., \& Chuang, A. (2010). Examining the mechanisms linking transformational leadership, employee customer orientation, and service performance: The mediating roles of perceived supervisor and coworker support. Journal of Business and Psychology, 25(3), 477-492.

Lin, H.-F., \& Lee, G.-G. (2005). Impact of organizational learning and knowledge management factors on e-business adoption. Management Decision, 43 (2), 171188.

Macintosh, G. (2007). Customer orientation, relationship quality, and relational benefits to the firm. Journal of Services Marketing, 21(3), 150-159.

May, D. R., Gilson, R. L., \& Harter, L. M. (2004). The psychological conditions of meaningfulness, safety and availability and the engagement of the human spirit at work. Journal of occupational and organizational psychology, 77(1), 11-37.

McBride, A.A., Mendoza, J.L. and Carraher, S.M. (1997). The development of biodata instrument to measure service orientation, Psychological Reports, Vol. 81 No. 3f, pp. 1395-1407.

Mead, G. H. (1934). Mind, Self and Society from the standpoint of a social behaviorist.[Edited and with an Introduction by Charles W. Morris]. University 
of Chicago Press, Chicago, London, 18, 1972.

Meere, M. (2005). The high cost of disengaged employees (Employee Engagement Industry Briefing). Hawthorne, Victoria: Swinburne University of Technology.

Min, S., Mentzer, J. T., \& Ladd, R. T. (2007). A market orientation in supply chain management. Journal of the Academy of Marketing Science, 35(4), 507-522.

Molina, L. M., Llor_ens-Montes, J., \& Ruiz-Moreno, A. (2007). Relationship between quality management practices and knowledge transfer. Journal of Operations Management, 25 (3), 682-701.

Palmatier, R. W., Dant, R. P., Grewal, D., \& Evans, K. R. (2006). Factors influencing the effectiveness of relationship marketing: a meta-analysis. Journal of marketing, 70(4), 136-153.

Popli, S., \&Rizvi, I. A. (2015). Exploring the relationship between service orientation, employee engagement and perceived leadership style: a study of managers in the private service sector organizations in India. Journal of Services Marketing, 29(1).

Roy Dholakia, R., \& Zhao, M. (2010). Effects of online store attributes on customer satisfaction and repurchase intentions. International Journal of Retail \& Distribution Management, 38(7), 482-496.

Sabiote, E. F., \&Román, S. (2009). The influence of social regard on the customer-service firm relationship: The moderating role of length of relationship. Journal of Business and Psychology, 24(4), 441-453.

Saks, A. M. (2006). Antecedents and consequences of employee engagement. Journal of managerial psychology, 21(7), 600-619.

Sarwar, M. Z., Abbasi, K. S., \&SaleemPervaiz, D. (2012). The effect of customer trust on customer loyalty and customer retention: A moderating role of cause related marketing. Global Journal of Management and Business Research, 12(6). 
Saxe, R., \&Weitz, B. A. (1982). The SOCO scale: a measure of the customer orientation of salespeople. Journal of marketing research, 343-351.

Shi, M., Chiang, J., \& Rhee, B. D. (2006). Price competition with reduced consumer switching costs: The case of "wireless number portability" in the cellular phone industry. Management Science, 52(1), 27-38.

Sirdeshmukh, D., Singh, J., \&Sabol, B. (2002). Consumer trust, value, and loyalty in relational exchanges. Journal of marketing, 66(1), 15-37.

Sluss, D. M., \&Ashforth, B. E. (2008). How relational and organizational identification converge: Processes and conditions. $\hat{E} O r g a n i z a t i o n ~ S c i e n c e, \hat{E} 19(6), 807-823$.

Spreitzer, G. M. (1995). Psychological empowerment in the workplace: Dimensions, measurement, and validation.EAcademy of management Journal,38(5), 14421465.

Teng, C. C., \& Barrows, C. W. (2009). Service orientation: antecedents, outcomes, and implications for hospitality research and practice. The Service Industries Journal, 29(10), 1413-1435.

Tsai, W. C., Chen, C. C., \& Liu, H. L. (2007). Test of a model linking employee positive moods and task performance. Journal of Applied Psychology, 92(6), 1570.

Tsaur, S. H., \& Lin, Y. C. (2004). Promoting service quality in tourist hotels: the role of HRM practices and service behavior. Tourism Management, 25(4), 471-481.

Valenzuela, L. M., Mulki, J. P., \& Jaramillo, J. F. (2010). Impact of customer orientation, inducements and ethics on loyalty to the firm: Customers' perspective. Journal of Business Ethics, 93(2), 277-291.

Vroom, V.H. (1967), Work and Motivation, 3rd ed., Jossey-Bass, New York, NY.

Yavas, U., \&Babakus, E. (2010). Relationships between organizational support, customer orientation, and work outcomes: A study of frontline bank employees. International 
Journal of Bank Marketing, 28(3), 222-238.

Zablah, A. R., Franke, G. R., Brown, T. J., \& Bartholomew, D. E. (2012). How and when does customer orientation influence frontline employee job outcomes? A meta-analytic evaluation. Journal of Marketing, 76(3), 21-40.

\section{APPENDIX}

Figure .1: Conceptual Model adopted from Hennig-Thurau, 200
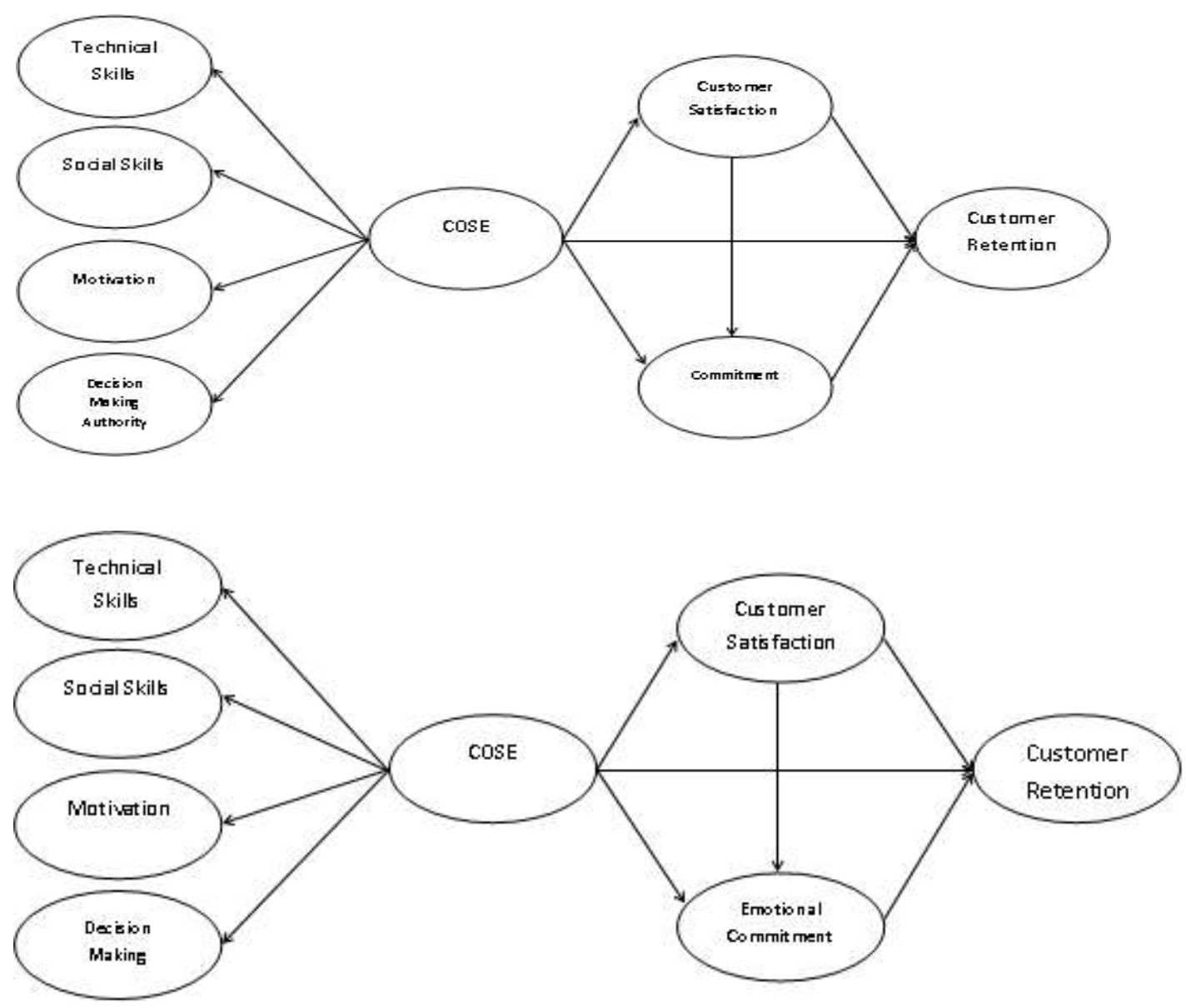

Figure .2: Hypothesized Model 


\section{Gender}

Frequency Percent Valid Percent Cumulative

\begin{tabular}{llllll}
\hline \multirow{3}{*}{ Valid } & Male & 137 & 55.9 & 55.9 & Perce \\
& Female & 108 & 44.1 & 44.1 & 55.9 \\
& Total & 245 & 100.0 & 100.0 & 100.0 \\
\hline \hline
\end{tabular}

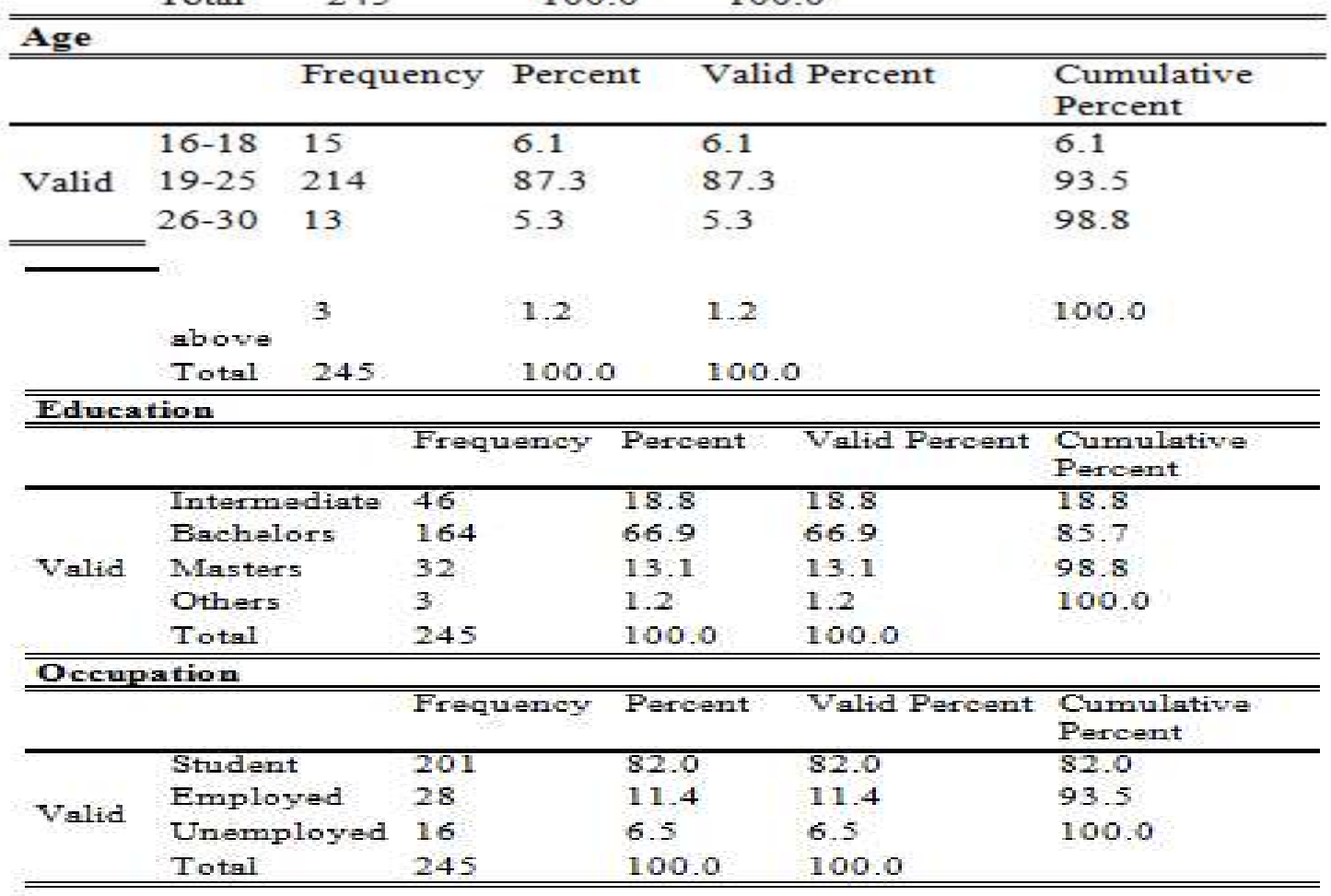

Mobile Network in use

\begin{tabular}{|c|c|c|c|c|c|}
\hline & & Frequency & Percent & Valid Percent & $\begin{array}{l}\text { Cumulative } \\
\text { Percent }\end{array}$ \\
\hline \multirow{6}{*}{ Valid } & Mobilink & 19 & 7.8 & 7.8 & 7.8 \\
\hline & Ufone & 129 & 52.7 & 52.7 & 60.4 \\
\hline & Warid & 23 & 9.4 & 9.4 & 69.8 \\
\hline & Zong & 24 & 9.8 & 9.8 & 79.6 \\
\hline & Telenor & 50 & 20.4 & 20.4 & 100.0 \\
\hline & Total & 245 & 100.0 & 100.0 & \\
\hline \multicolumn{6}{|c|}{ Usage Duration } \\
\hline & & Frequency & Percent & Valid Percent & $\begin{array}{l}\text { Cumulati } \\
\text { ve } \\
\text { Percent }\end{array}$ \\
\hline \multirow{5}{*}{ Valid } & $\begin{array}{l}\text { less than } 1 \\
\text { year }\end{array}$ & 8 & 3.3 & 3.3 & 3.3 \\
\hline & $1-2$ years & 50 & 20.4 & 20.4 & 23.7 \\
\hline & $2-3$ years & 41 & 16.7 & 16.7 & 40.4 \\
\hline & $\begin{array}{l}3 \text { years } \\
\text { and above }\end{array}$ & 146 & 59.6 & 59.6 & 100.0 \\
\hline & Total & 245 & 100.0 & 100.0 & \\
\hline
\end{tabular}


Table.1: Descriptive Statistics of Data Set

\begin{tabular}{lllllll}
\hline \hline & COSE & $\begin{array}{l}\text { Customer } \\
\text { Satisfaction }\end{array}$ & $\begin{array}{l}\text { Emotional_ } \\
\text { Commitment }\end{array}$ & $\begin{array}{l}\text { Customer_ } \\
\text { Retention }\end{array}$ & Skewness & Kurtosis \\
\hline COSE & 1.000 & & & & -0.601 & 0.335 \\
$\begin{array}{l}\text { Customer } \\
\begin{array}{l}\text { Satisfaction } \\
\text { Emotional }\end{array}\end{array}$ & .811 & 1.000 & & & -0.638 & 0.110 \\
$\begin{array}{l}\text { Commitment } \\
\text { Customer }\end{array}$ & .610 & .830 & 1.000 & & -0.561 & 0.585 \\
Retention & .662 & .758 & .898 & 1.000 & -0.618 & 0.436 \\
\hline \hline
\end{tabular}

Table.2: Normality and Multi-collinearity Diagnostics

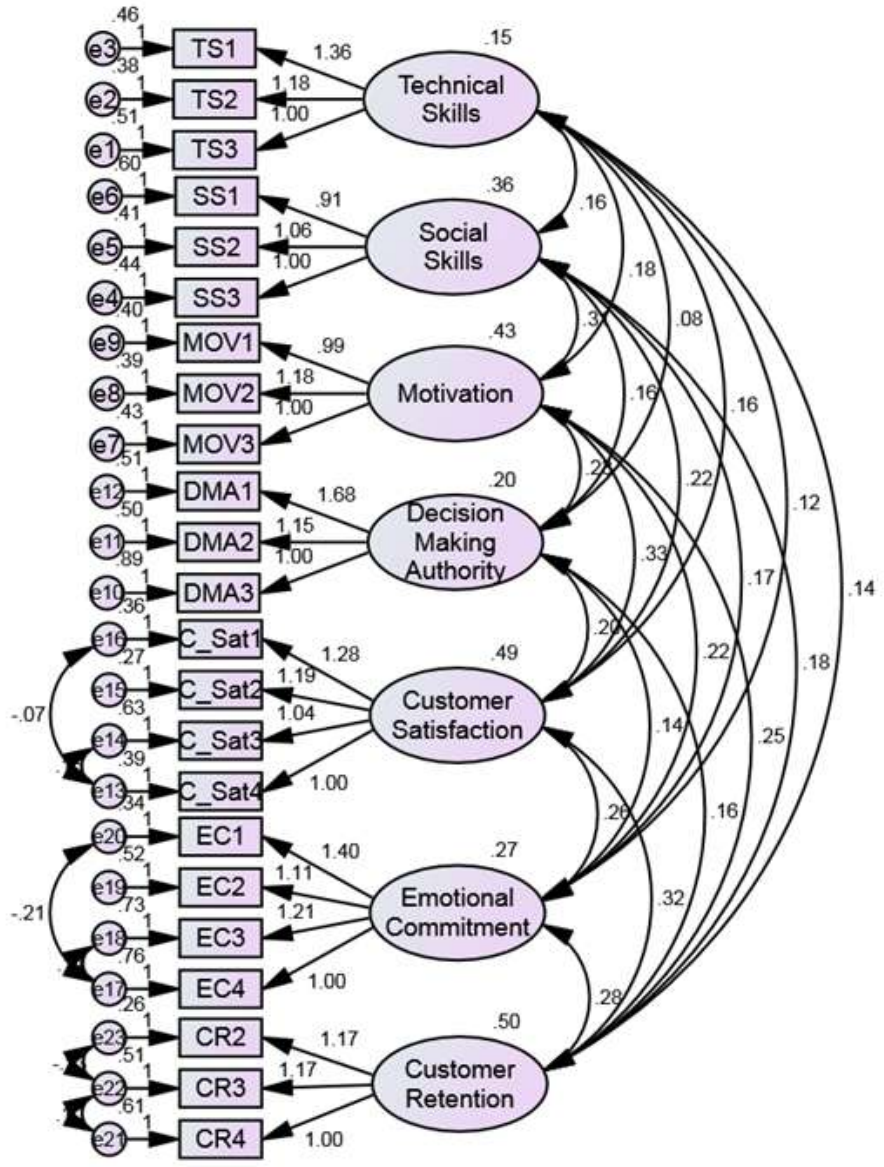

Figure .3 


\begin{tabular}{lllll}
\hline \hline & CMIN/DF & CFI & TLI & RMSEA \\
\hline Null Model & 9.522 & 0.000 & 0.000 & 0.187 \\
One Factor Model & 3.093 & 0.783 & 0.754 & 0.104 \\
Two Factor Model & 3.305 & 0.755 & 0.730 & 0.097 \\
Hypothesized & $1.788 * * *$ & 0.926 & 0.907 & 0.057 \\
$\begin{array}{l}\text { Model } \\
\text { (CFA Model) }\end{array}$ & & & & \\
2nd Order CFA & $1.801 * * *$ & 0.921 & 0.906 & 0.057 \\
\hline \hline
\end{tabular}

Table .4: Measures of Model Fit

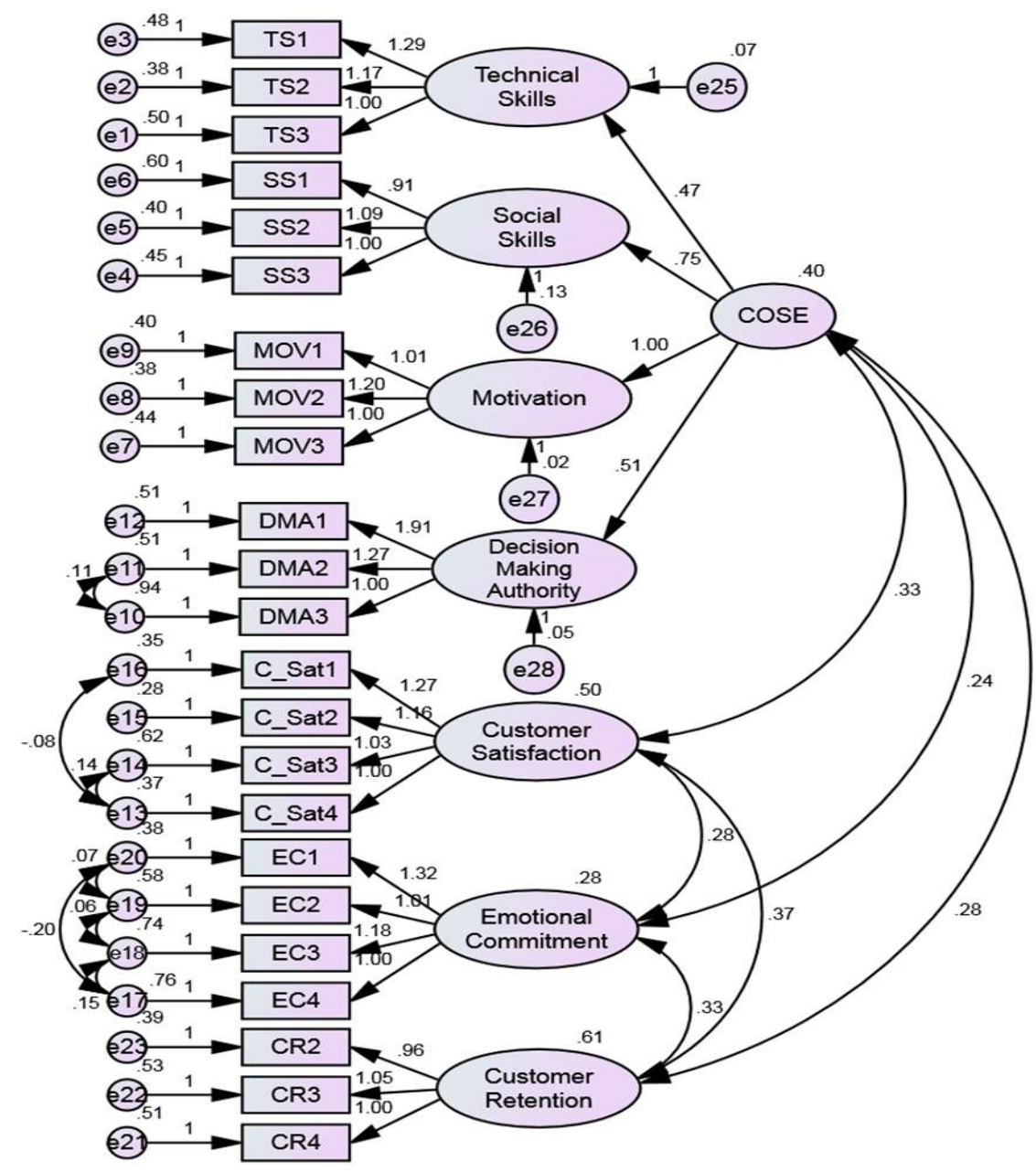

Figure .5 


\begin{tabular}{|c|c|c|}
\hline Social Skills & Adapted From & $\mathrm{CR}$ \\
\hline \multicolumn{3}{|c|}{$\begin{array}{l}\text { Indication } \\
\text { in CRA } \\
\text { Modal }\end{array}$} \\
\hline \$SI & $\begin{array}{l}\text { The employeas of the mobile network have extensive social } \\
\text { fkills }\end{array}$ & \\
\hline$\$ 2$ & $\begin{array}{l}\text { The employees of the mobila network are abla to consider Hemnig-Thurau, } 2004 \\
\text { their customers' perspective. }\end{array}$ & $\mathrm{a}=0.71$ \\
\hline$\$ 3$ & $\begin{array}{l}\text { The employees of the mobile netwok hnow how to treat a } \\
\text { customes well. }\end{array}$ & \\
\hline \multicolumn{3}{|l|}{ Technical Skills } \\
\hline TSI & $\begin{array}{l}\text { The employes of the mobile network have a high lave of } \\
\text { knowledge. }\end{array}$ & $\mathrm{CR}=0.70$ \\
\hline TS2 & The mobile network's amployees are expats in their job. Hennig-Thurau, 2004 & \\
\hline TS3 & The employes of the mobile network are highly competent & \\
\hline \multicolumn{3}{|l|}{ Motivation } \\
\hline MOVI & $\begin{array}{l}\text { The employees of the mobile network show strong commitmant } \\
\text { to their job. }\end{array}$ & \\
\hline MOV2 & $\begin{array}{l}\text { The employees of the mobile netrork do their best to fulfill Hemnig-Thurau, } 2004 \\
\text { their customers' needs. }\end{array}$ & $\mathrm{CR}=0.779$ \\
\hline MOV3 & $\begin{array}{l}\text { The employees of the mobile netrork are always highly } \\
\text { motivatad. }\end{array}$ & \\
\hline
\end{tabular}

\section{Decision Making Authority}

DMAI The employes of the mobila natwork are allowed to decide autonomously in customer matters.

DMA2 The employees of the mobile network have appropriate room Hennig-Thurau, $2004 \quad \mathrm{CR}=0.701$ for maneuver in solving customer problems.

DMA3 In the case of customer requests, the mobile network's employees do not need to ask their superiof for permission.

CSatl I am fully satisfied with the mobile natwork.

CSat2 The mobile network always fulfills my empectations.

Hennig-Thurau, $2004 \quad \mathrm{OR}=0.859$

CSat The mobile network has never disappointed me so far. 
C_Sat4 My experiences with the mobile network are excellent.

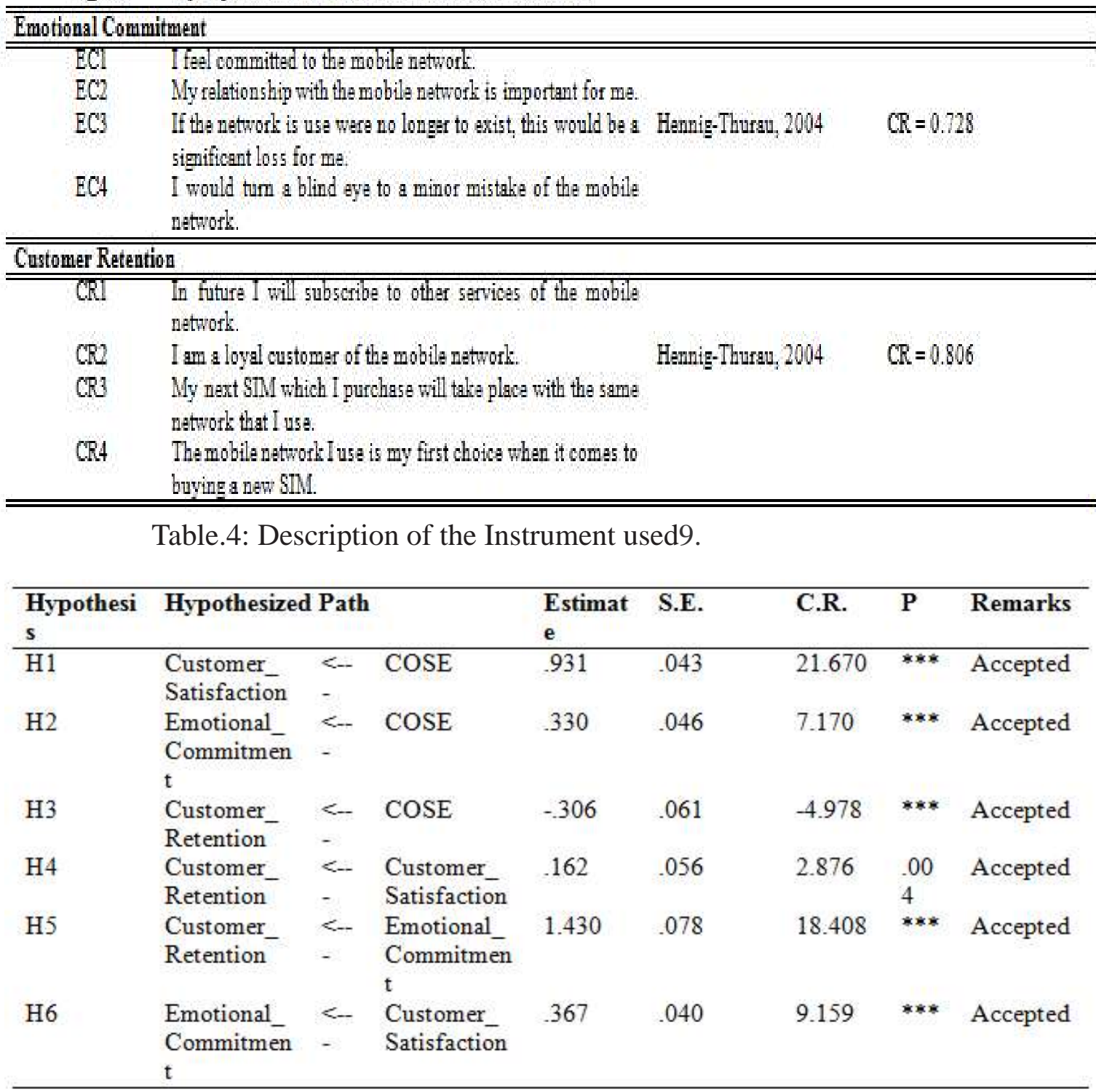

Table .5: Hypothesis Testing 


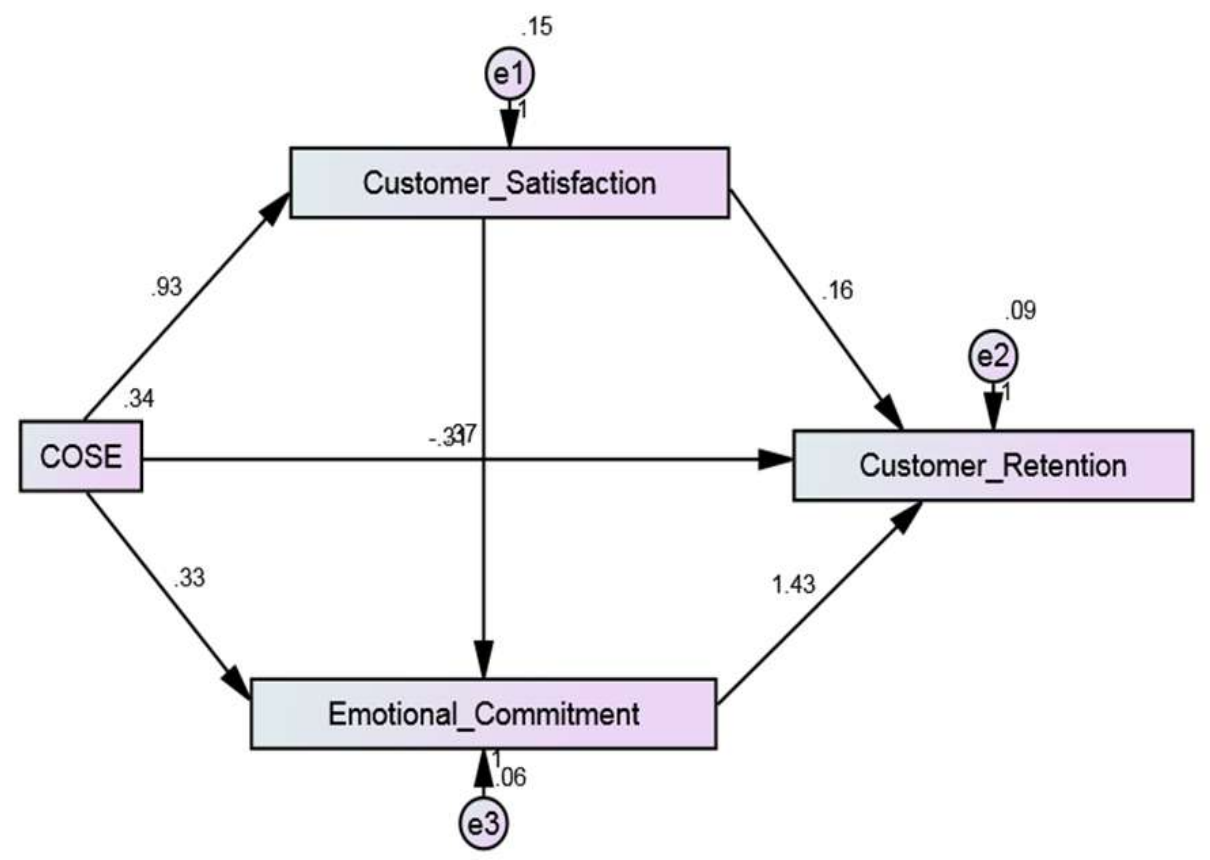

Figure.6

\begin{tabular}{lllll}
\hline \hline & Total Effect & Indirect Effect & Direct Effect & Remarks \\
& IV (COSE) & IV (COSE) & IV (COSE) & \\
\hline DV & $0.805^{* * *}$ & $1.111^{* * *}$ & $-0.306^{* * *}$ & Partial Mediation \\
(Customer & & & & \\
Retention) & & & & \\
\hline \hline
\end{tabular}

Table - 6: Mediation Effect

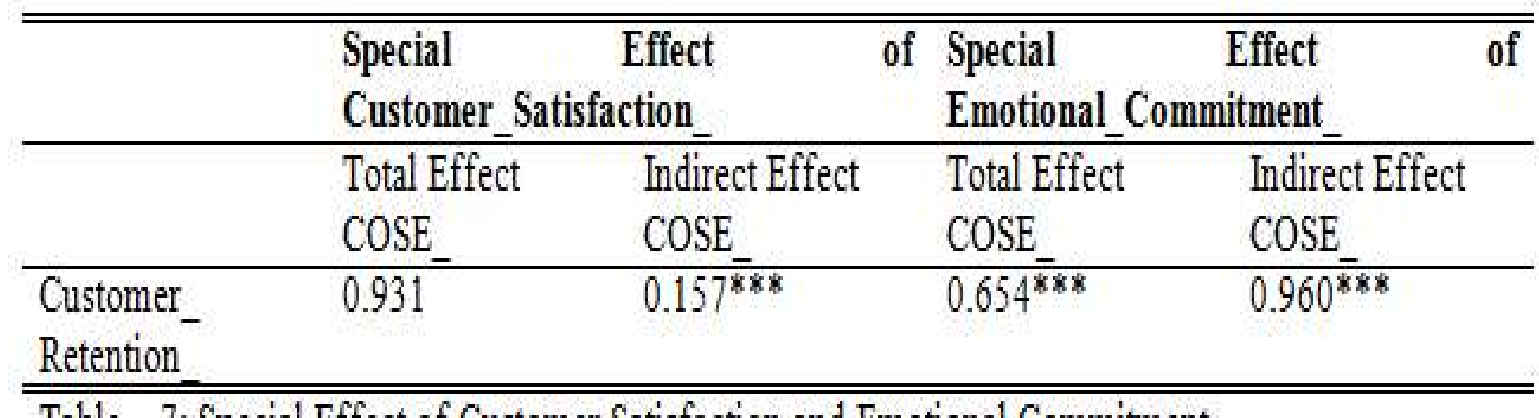

Table - 7: Special Effect of Customer Satisfaction and Emotional Commitment 